\title{
Article \\ Efficacy and Safety of Isotonic and Hypotonic Intravenous Maintenance Fluids in Hospitalised Children: A Systematic Review and Meta-Analysis of Randomised Controlled Trials
}

\author{
Norfarahin Hasim 1,2, Mimi Azliha Abu Bakar 1,2,* and Md Asiful Islam ${ }^{3, * \mathbb{D}}$ \\ 1 Department of Emergency Medicine, School of Medical Sciences, Universiti Sains Malaysia, \\ Kubang Kerian 16150, Kelantan, Malaysia; farahinhashim@student.usm.my \\ 2 Hospital Universiti Sains Malaysia, Kubang Kerian 16150, Kelantan, Malaysia \\ 3 Department of Haematology, School of Medical Sciences, Universiti Sains Malaysia, \\ Kubang Kerian 16150, Kelantan, Malaysia \\ * Correspondence: azliha79@usm.my (M.A.A.B.); asiful@usm.my or ayoncx70@yahoo.com (M.A.I.)
}

check for

updates

Citation: Hasim, N.; Bakar, M.A.A.; Islam, M.A. Efficacy and Safety of Isotonic and Hypotonic Intravenous Maintenance Fluids in Hospitalised Children: A Systematic Review and Meta-Analysis of Randomised Controlled Trials. Children 2021, 8 , 785. https://doi.org/10.3390/ children 8090785

Academic Editor: Michael L. Moritz

Received: 25 June 2021

Accepted: 7 September 2021

Published: 8 September 2021

Publisher's Note: MDPI stays neutral with regard to jurisdictional claims in published maps and institutional affiliations.

Copyright: (C) 2021 by the authors. Licensee MDPI, Basel, Switzerland. This article is an open access article distributed under the terms and conditions of the Creative Commons Attribution (CC BY) license (https:// creativecommons.org/licenses/by/ $4.0 /)$.

\begin{abstract}
Hyponatraemia is a known complication in hospitalised children receiving maintenance intravenous fluid. Several studies have been published to investigate the efficacy and safety of intravenous fluids in children. However, there is still an ongoing debate regarding the ideal solution to be used in the paediatric population. Therefore, the aim of this meta-analysis was to investigate the safety and efficacy of administering isotonic versus hypotonic intravenous maintenance fluid in hospitalised children. An extensive search was undertaken on PubMed, Web of Science, Scopus, ScienceDirect, Google Scholar and Cochrane Library on 28 December 2020. Only randomised controlled trials (RCTs) were included. We used the random-effects model for all analyses. Risk ratio (RR) and mean difference with 95\% confidence intervals (CIs) were used for dichotomous and continuous outcomes, respectively. The quality of each study was assessed using the Joanna Briggs Institute critical appraisal tool for RCTs. This study is registered with PROSPERO (CRD42021229067). Twenty-two RCTs with a total of 3795 participants were included. The studies encompassed surgical and medical patients admitted to intensive care unit as well as to general wards. We found that hypotonic fluid significantly increases the risk of hyponatremia at both $\leq 24 \mathrm{~h}$ (RR $0.34 ; 95 \% \mathrm{CI}$ : $0.26-0.43, p<0.00001)$ and $>24 \mathrm{~h}$ (RR 0.48; 95\% CI: 0.36-0.64, $p<0.00001)$. Isotonic fluid increases the risk of hypernatraemia at $\leq 24 \mathrm{~h}$ (RR 2.15; 95\% CI: $1.24-3.73, p=0.006$ ). The prevalence of hyponatraemia was also higher in the hypotonic group at both $\leq 24 \mathrm{~h}(5.7 \%$ vs. $23.3 \%)$ and $>24 \mathrm{~h}(6.0 \%$ vs. $26.3 \%$ ). There was no statistically significant difference in the risk of developing adverse outcomes between the two groups. Mean serum and urine sodium as well as serum osmolality/osmolarity was lower in the hypotonic group. Isotonic solution is protective against the development of hyponatraemia while hypotonic solution increases the risk of hyponatraemia.
\end{abstract}

Keywords: isotonic; hypotonic; intravenous fluid; efficacy; safety; hospitalised; children; systematic review; meta-analysis

\section{Introduction}

The practice of prescribing hypotonic solution as maintenance intravenous fluid (IVF) in children was made popular more than six decades ago following the recommendation proposed by Holliday and Segar in 1957 [1]. Their recommendations were derived based on the caloric expenditure of healthy children as well as the electrolyte composition of human and cow's milk [1]. These days, this equates to a $0.2 \%$ sodium chloride in a $5 \%$ dextrose solution [2], which is markedly hypotonic in comparison to plasma tonicity. This practice has since been called into question. Moritz and Ayus [3], in their 2003 review, highlighted the dangers of prescribing hypotonic fluid in children. They reported over 50 deaths and significant undesirable neurological outcomes linked to hypotonic fluid; 
hence, they proposed that an isotonic solution would be a better choice as maintenance IVF in children.

The goal of initiating maintenance IVF is to help maintain a normal electrolyte balance when oral intake is insufficient to preserve the extracellular volume [4-6]. A wide range of fluids is commercially available. They can all be classified as either isotonic or hypotonic solutions. The osmolality of an isotonic solution is equal to or close to that of plasma $(275-295 \mathrm{mOsm} / \mathrm{kg})$, whereas the osmolality of a hypotonic solution is lower than that of plasma [7]. The constituents of these fluids differ from one another [8-10]. The variety of available fluids, combined with a lack of knowledge about their components, can make it difficult for physicians to choose the best solution for their patients [11-13].

The main concerns of using hypotonic solution are the development of hyponatraemia and its neurological effects. Hyponatraemia in the hospitalised paediatric population results from two factors. The first is the administration of electrolyte-free water such as hypotonic saline and the second is the secretion of antidiuretic hormone (ADH) from the posterior pituitary gland, which prevents the excretion of this electrolyte-free water [14]. This effect of the hypotonic solution makes it less desirable as IVF in children. Isotonic fluid does not affect plasma osmolality since it contains sodium at physiological plasma concentrations [15]. The infused isotonic fluid will be distributed freely within the extracellular fluid (ECF) compartment causing a minimal change in the sodium concentration and osmolality [16], thereby, limiting the movement of water from the ECF into the intracellular fluid (ICF) compartment and vice versa. This lack of shift of water between the ECF and ICF is critical in preventing cerebral oedema caused by hyponatraemia which can lead to significant neurological morbidity.

Little attention has been placed on urine chemistries; however, they are important in the workup for dysnatraemia [17-19]. There are no "normal values" for urine electrolyte concentrations, but there are "expected values" $[17,18]$. The findings of these figures must be interpreted in light of the clinical context. For example, in a dehydrated patient, urine sodium is anticipated to be low as there will be water conservation. When dealing with dysnatraemia, it may be possible to determine the cause of the electrolyte imbalance by combining the results of plasma and urine osmolality with urine sodium as well as clinical examination $[18,20,21]$.

The American Academy of Pediatrics (AAP) published a guideline in 2018 recommending isotonic solutions as intravenous maintenance fluid therapy in children aged from 28 days to 18 years old [5]. The National Institute for Health and Care Excellence (NICE) issued an updated guideline in 2020 that suggested the use of isotonic fluid in term neonates over eight days old [22]. Since the publication of these guidelines, there has been a shift towards prescribing isotonic solutions [23,24] among physicians compared to previous years [25-29]. Several interventional studies have been carried out to improve adherence to the recommendation by AAP $[30,31]$. These studies reveal that although guidelines are available, there are still physicians who prescribe hypotonic fluid as IVF in children.

Despite mounting evidence of the dangers of using hypotonic IVF, many physicians continue to recommend it. There may exist doubts regarding the safety of isotonic fluid due to concerns that it might induce hypernatraemia and fluid overload [32,33] in children. Therefore, we intend to investigate the efficacy and safety of isotonic versus hypotonic solutions as maintenance IVF in hospitalised children by conducting a systematic review and meta-analysis. We also aimed to analyse the occurrence of adverse events associated with IVF.

\section{Methods}

\subsection{Search Strategy}

In accordance with the PRISMA guidelines [34], we conducted a systematic review and meta-analysis of the literature to identify studies that compared the effects of isotonic versus hypotonic maintenance fluid in hospitalised children. This study is registered with 
the PROSPERO database (registration number: CRD42021229067). Initial searches were not restricted by date, language, or study design. PubMed, Web of Science, Scopus, Google Scholar, and Cochrane Library databases were searched on 28 December 2020. The following keywords were searched: isotonic, hypotonic, saline, hyponatremia, hyponatraemia, children, pediatric, paediatric, pediatrics, paediatrics, adolescent, adolescents, child, infant, infants, newborn, and newborns. Complete detail of search strategies is in the Supplementary Table S1. The listed studies' references were also reviewed to ensure a thorough search. Using the EndNote X8 programme, we were able to remove duplicate studies.

\subsection{Eligibility Criteria}

The population considered were hospitalised patients aged newborn till 18 years old with any medical or surgical conditions requiring maintenance IVF. Our aim was to analyse isotonic versus hypotonic fluid as maintenance IVF in hospitalised children. The primary outcome was hyponatraemia (defined as serum sodium $\leq 135 \mathrm{mmol} / \mathrm{L}$ ). Secondary outcomes were hypernatraemia (defined as serum sodium $\geq 145 \mathrm{mmol} / \mathrm{L}$ ), change in serum and urine sodium levels following infusion of fluid, serum osmolality/osmolarity, and adverse outcomes observed during the study. Hypotonic fluid is defined as any fluid which has tonicity lower than that of $0.9 \%$ sodium chloride, such as $0.45 \%$ sodium chloride or $0.18 \%$ sodium chloride. An isotonic fluid is defined as normal saline (0.9\%), Hartmann's solution, Ringer's lactate, and any other fluid with osmolality close to that of plasma [35]. Other inclusion criteria were as follows: randomised controlled trials and studies comparing isotonic with hypotonic fluid. The following were excluded: review articles, conference abstracts, animal studies, opinions and perspectives, non-randomised controlled trials, and case reports. Data gathered from databases, websites or reported in press releases and news reports were not considered. Additionally excluded were studies that involved patients with dysnatraemia before starting the study that is defined as serum sodium $\leq$ 130 or $\geq 145 \mathrm{mmol} / \mathrm{L}$.

\subsection{Study Selection}

The titles and abstracts of articles of interest were first screened to identify eligible studies. Following that, the full texts of the aforementioned articles were evaluated. Disagreements regarding including a study were resolved after discussion among authors.

\subsection{Data Extraction}

One author (N.H.) extracted the data of interest, and other authors (M.A.I. and M.A.A.B.) cross-checked the data independently and disagreements were resolved by discussions. From each of the eligible studies, the following information were entered into an Excel spreadsheet: first author's last name, year and country of the study, duration of follow-up, total number of participants, characteristic of the study population (number, age, and surgical or medical condition), description of interventions and comparisons as well as outcomes.

\subsection{Subgroup and Sensitivity Analyses}

All the primary and secondary outcomes except adverse events were subgrouped based on the duration of the fluid interventions (i.e., $\leq 24$ and $>24 \mathrm{~h}$ ). Whenever there were multiple outcome measurement times (i.e., $8,12,18,36,48$, and $72 \mathrm{~h}$ ), the data at the longest fluid administration time was selected for analysis and to avoid duplication of data. In addition, we conducted another subgroup analysis based on different concentrations of the maintenance fluids (i.e., $0.9 \%$ vs. $0.45 \%$ and $0.9 \%$ vs. $0.18 \%$ ). All sensitivity analyses were carried out with data taken at $24 \mathrm{~h}$. This time point was chosen as most studies had outcome measurements at $24 \mathrm{~h}$. We performed sensitivity analyses for the risks of hyponatraemia and hypernatraemia, as well as the mean difference in serum and urine sodium after excluding small studies with less than 100 participants, low- or mediumquality studies, and if we were to conduct the analysis using a fixed-effects model [36,37]. 
We also performed an additional sensitivity analysis excluding studies that had changes in the types of maintenance fluid during the study period for risks of hyponatraemia and hypernatraemia.

\subsection{Quality Assessment and Publication Bias}

Two authors (N.H. and M.A.A.B.) independently evaluated the quality of included studies using the Joanna Briggs Institute critical appraisal tool for randomised controlled trials [38]. If the total score was $<50 \%, 50-70 \%$, or $>70 \%$, the studies were categorised as low quality (high risk of bias), moderate quality (moderate risk of bias), and high quality (low risk of bias) [37,39]. In main and subgroup analysis, if there was a minimum of 10 studies, publication bias was analysed and visually represented assessing the primary outcomes (i.e., hyponatraemia and hypernatraemia).

\subsection{Data Analysis}

Risk ratio (RR) and mean difference (MD) with 95\% confidence intervals (CIs) were used for dichotomous and continuous outcomes, respectively. Additionally, pooled prevalence was estimated with $95 \% \mathrm{CI}$. All the analyses were calculated using the random-effects model. We employed the Mantel-Haenzel method to estimate dichotomous outcomes and the inverse variance analysis method for the continuous outcomes. The $I^{2}$ statistic was used to assess heterogeneity $\left(I^{2}>75 \%\right.$ indicating significant heterogeneity), as well as Cochran's Q-test to establish the significance of heterogeneity. RevMan (version 5.4) was used to create all of the analyses and plots [40] and metaprop codes in meta (version 4.15-1) and metafor (version 2.4-0) packages of $R$ (version 3.6.3) in RStudio (version 1.3.1093) software (RStudio, Inc., Boston, MA, USA) [23].

\section{Results}

\subsection{Study Selection}

Our initial search identified 1125 studies. We eliminated 688 articles for the following reasons: non-human subjects $(n=5)$; review articles $(n=54)$; case reports $(n=56)$; editorials and comments $(n=5)$; duplicate studies $(n=568)$. In total, 437 studies were screened for eligibility, from which 415 were removed as they did not meet the objective of the meta-analysis. The full texts of the remaining 22 studies were reviewed, and finally, all these 22 studies were included (Figure 1).

\subsection{Study Characteristics}

Table 1 summarises the major characteristics of the included studies. This metaanalysis is based on a study of 3795 patients hospitalised for various surgical and medical conditions. The studies were conducted in nine different countries: India $(n=8)$, Australia $(n=3)$, Canada $(n=4)$, Argentina $(n=2)$, Portugal $(n=1)$, Finland $(n=1)$, Poland $(n=1)$, Spain $(n=1)$, and Nigeria $(n=1)$. Sixteen $(72.7 \%)$ of the studies used $0.9 \%$ sodium chloride as the isotonic solution. Ten (45.5\%) of the studies used $0.45 \%$ sodium chloride as the hypotonic solution. The duration of fluid therapy and the timing of outcome measurements varied between studies, ranging from less than $8 \mathrm{~h}$ to seven days after the start of the maintenance IVF. 


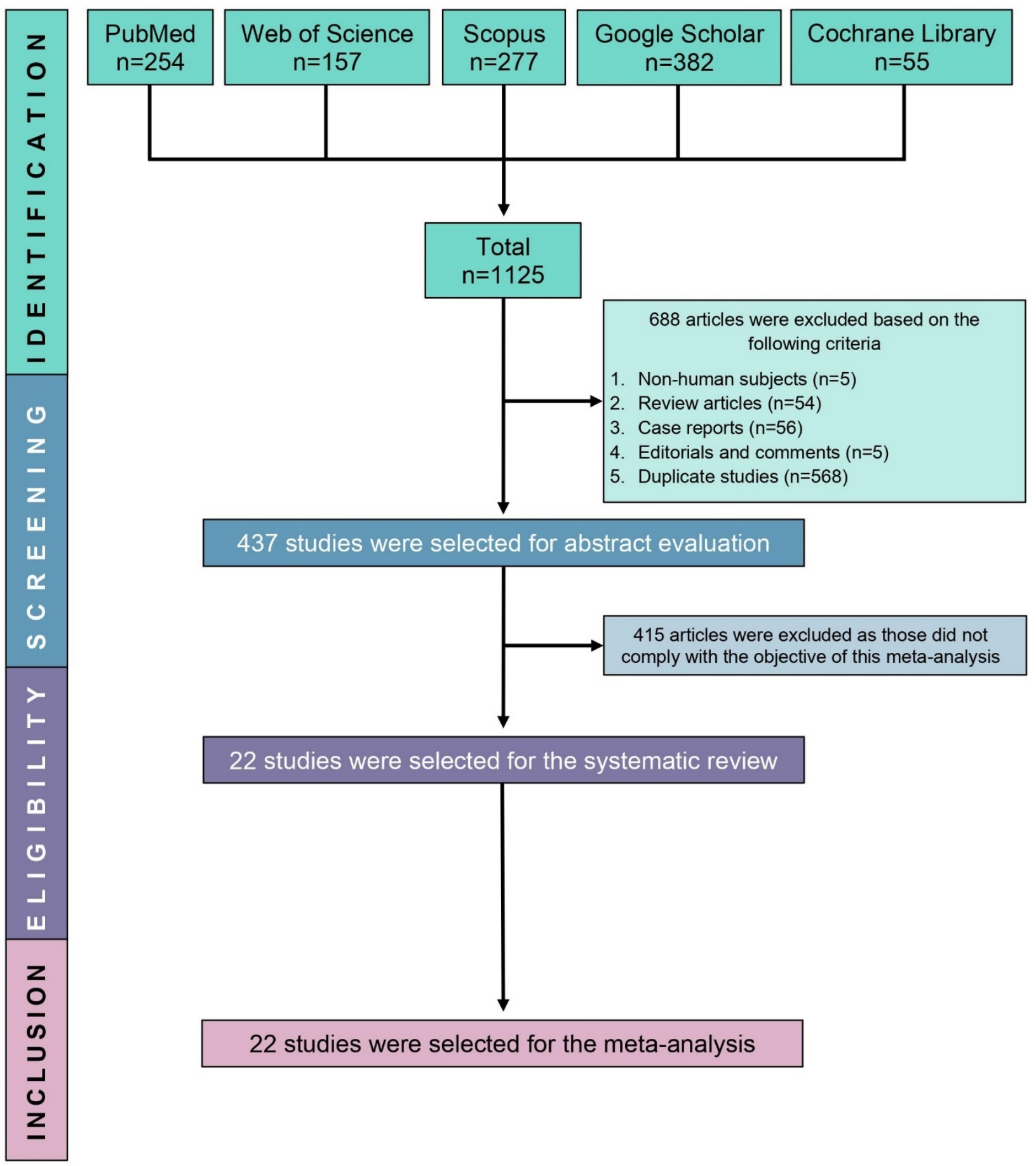

Figure 1. PRISMA flow diagram of study selection. 
Table 1. Characteristics of included RCTs of hypotonic vs. isotonic maintenance intravenous fluid therapy in hospitalised children.

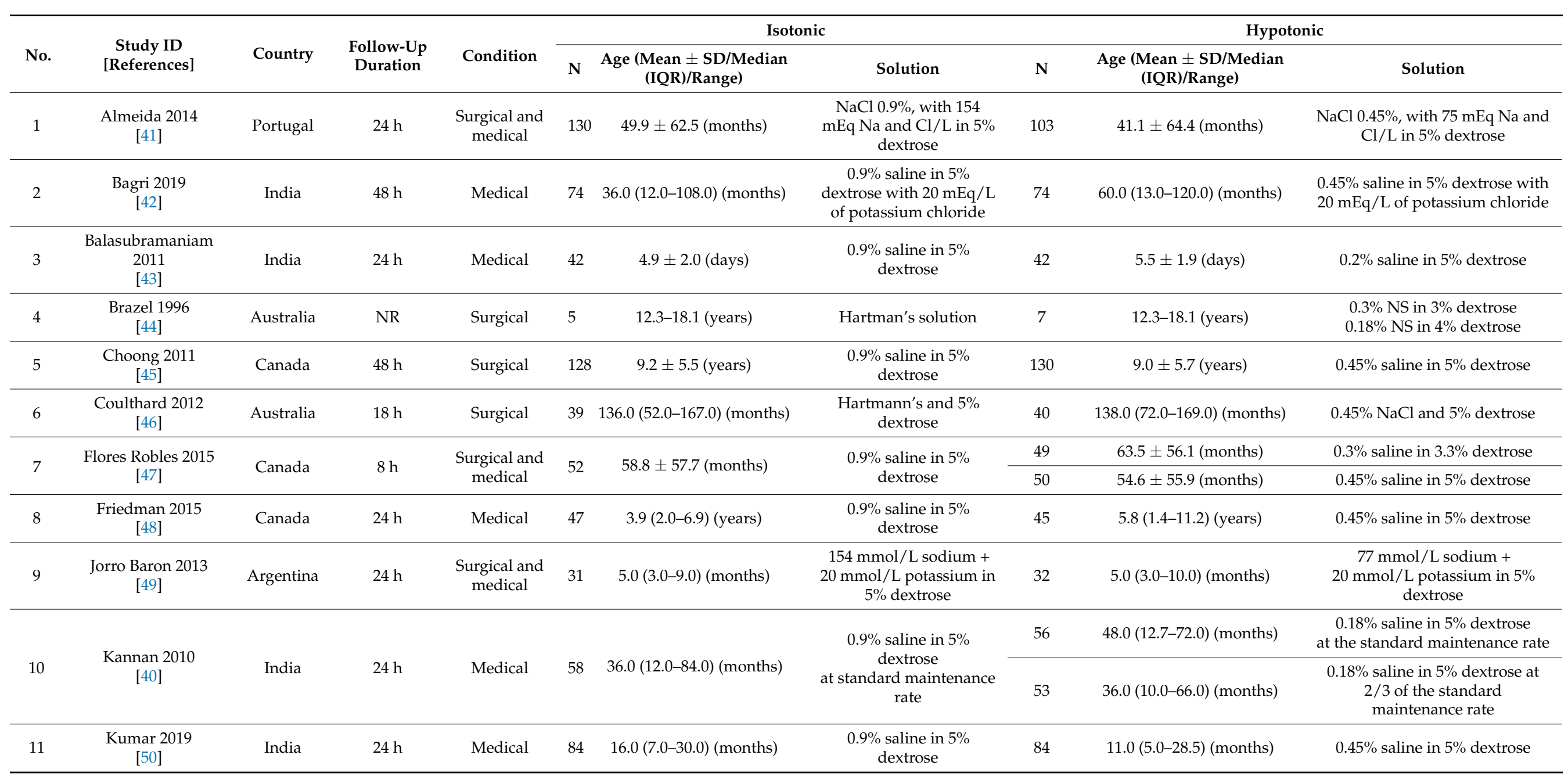


Table 1. Cont..

\begin{tabular}{|c|c|c|c|c|c|c|c|c|c|c|}
\hline \multirow[b]{2}{*}{ No. } & \multirow{2}{*}{$\begin{array}{l}\text { Study ID } \\
\text { [References] }\end{array}$} & \multirow[b]{2}{*}{ Country } & \multirow{2}{*}{$\begin{array}{l}\text { Follow-Up } \\
\text { Duration }\end{array}$} & \multirow[b]{2}{*}{ Condition } & \multicolumn{3}{|c|}{ Isotonic } & \multicolumn{3}{|c|}{ Hypotonic } \\
\hline & & & & & $\mathbf{N}$ & $\begin{array}{c}\text { Age (Mean } \pm \text { SD/Median } \\
\text { (IQR)/Range) }\end{array}$ & Solution & $\mathbf{N}$ & $\begin{array}{c}\text { Age (Mean } \pm \text { SD/Median } \\
(\text { IQR)/Range) }\end{array}$ & Solution \\
\hline 12 & $\begin{array}{c}\text { Lehtiranta } 2020 \\
{[51]}\end{array}$ & Finland & 7 days & $\begin{array}{l}\text { Surgical and } \\
\text { medical }\end{array}$ & 308 & $4.0 \pm 3.1$ (years) & $\begin{array}{l}140 \mathrm{mmol} / \mathrm{L} \text { of sodium } \\
\text { and } 5 \mathrm{mmol} / \mathrm{L} \\
\text { potassium in } 5 \% \\
\text { dextrose }\end{array}$ & 306 & $4.1 \pm 3.1$ (years) & $\begin{array}{c}80 \mathrm{mmol} / \mathrm{L} \text { sodium and } 20 \\
\mathrm{mmol} / \mathrm{L} \text { potassium in } 5 \% \\
\text { dextrose }\end{array}$ \\
\hline 13 & $\begin{array}{c}\text { McNab } 2014 \\
{[52]}\end{array}$ & Australia & $72 \mathrm{~h}$ & Surgical & 319 & $8.2 \pm 5.4$ (years) & $140 \mathrm{mmol} / \mathrm{L}$ of sodium & 322 & $8.9 \pm 5.3$ (years) & $77 \mathrm{mmol} / \mathrm{L}$ of sodium \\
\hline 14 & $\begin{array}{c}\text { Mierzewska- } \\
\text { Schmidt } 2015 \\
{[53]}\end{array}$ & Poland & NR & Surgical & 30 & $6.1 \pm 2.1$ (years) & Ringer's acetate & 27 & $6.5 \pm 2.5$ (years) & $3.33 \%$ glucose in $0.3 \% \mathrm{NaCl}$ \\
\hline 15 & $\begin{array}{c}\text { Montanana } 2008 \\
{[54]}\end{array}$ & Spain & $24 \mathrm{~h}$ & $\begin{array}{l}\text { Surgical and } \\
\text { medical }\end{array}$ & 51 & $3.2(1.3-10.0)$ (years) & $\begin{array}{c}140 \mathrm{mEq} / \mathrm{L} \text { sodium }+ \\
15 \mathrm{mEq} / \mathrm{L} \text { potassium in } \\
5 \% \text { dextrose }\end{array}$ & 52 & 3.0 (0.9-7.0) (years) & $\begin{array}{c}20 \text { and } 100 \mathrm{mEq} / \mathrm{L} \text { sodium in } 5 \% \\
\text { dextrose }\end{array}$ \\
\hline 16 & $\begin{array}{c}\text { Omoifo } 2018 \\
{[55]}\end{array}$ & Nigeria & NR & Surgical & 20 & $5.9 \pm 3.5$ (years) & Normal saline & 25 & $6.5 \pm 3.7$ (years) & $4.3 \%$ dextrose in 0.18 saline \\
\hline \multirow{2}{*}{17} & \multirow{2}{*}{$\begin{array}{l}\text { Pemde } 2015 \\
{[56]}\end{array}$} & \multirow{2}{*}{ India } & \multirow{2}{*}{$24 \mathrm{~h}$} & \multirow{2}{*}{ Medical } & \multirow{2}{*}{31} & \multirow{2}{*}{$26.2 \pm 19.6$ ) (months) } & \multirow{2}{*}{$\begin{array}{l}0.9 \% \text { saline in } 5 \% \\
\quad \text { dextrose }\end{array}$} & 30 & $31.9 \pm 20.7$ (months) & $0.45 \%$ saline in $5 \%$ dextrose \\
\hline & & & & & & & & 31 & $28.2 \pm 21.2$ (months) & $0.18 \%$ saline in $5 \%$ dextrose \\
\hline 19 & $\begin{array}{c}\text { Raksha } 2017 \\
{[58]}\end{array}$ & India & $24 \mathrm{~h}$ & Medical & 120 & 1.0 month-18.0 years old & $\begin{array}{c}0.9 \% \text { saline in } 5 \% \\
\text { dextrose with } 20 \mathrm{mEq} / \mathrm{L} \\
\text { of potassium } \\
\text { chloride at standard } \\
\text { maintenance rate }\end{array}$ & 120 & 1.0 month-18.0 years old & $\begin{array}{c}0.18 \% \text { saline in } 5 \% \\
\text { dextrose/isolyte-p at } 2 / 3 \\
\text { standard maintenance rate }\end{array}$ \\
\hline 20 & $\begin{array}{l}\text { Saba } 2011 \\
\text { [59] }\end{array}$ & Canada & $8 \mathrm{~h}$ & $\begin{array}{l}\text { Surgical and } \\
\text { medical }\end{array}$ & 16 & $8.2(2.8-14.3)$ (years) & $\begin{array}{l}0.9 \% \text { saline in } 5 \% \\
\text { dextrose }\end{array}$ & 21 & 8.9 (1.7-16.5) (years) & $0.45 \%$ saline in $5 \%$ dextrose \\
\hline 21 & Shamim 2014 & India & $48 \mathrm{~h}$ & Medical & 30 & $53.1 \pm 39.5$ (months) & $\begin{array}{c}0.9 \% \mathrm{NaCl} \text { in } 5 \% \\
\text { dextrose at the rate of } \\
60 \% \text { of standard } \\
\text { maintenance volume }\end{array}$ & 30 & $54.4 \pm 31.7$ (months) & $\begin{array}{c}0.18 \% \mathrm{NaCl} \text { in } 5 \% \text { dextrose at the } \\
\text { rate of standard maintenance } \\
\text { volume }\end{array}$ \\
\hline 22 & $\begin{array}{l}\text { Torres } 2019 \\
{[61]}\end{array}$ & Argentina & $24 \mathrm{~h}$ & $\begin{array}{l}\text { Surgical and } \\
\text { medical }\end{array}$ & 145 & 18.0 (2.0-110.0) (months) & $\begin{array}{l}0.9 \% \text { saline in } 5 \% \\
\text { dextrose }\end{array}$ & 154 & 21.0 (3.0-109.0) (months) & $0.45 \%$ saline in $5 \%$ dextrose \\
\hline
\end{tabular}




\subsection{Primary Outcomes}

Our subgroup analysis at $8,12,18,24,36,48$, and $72 \mathrm{~h}$ showed that isotonic fluid reduced the risk of hyponatraemia where the lowest relative risks were observed at $18 \mathrm{~h}$ (RR 0.21; 95\% CI: 0.07-0.59) and 36 h (RR 0.21; 95\% CI: 0.07-0.67) (Figure S1). Figure 2, Figure 3 and Figure S2 summarise the analyses on risks and prevalence of hyponatraemia following infusion of isotonic and hypotonic fluids. Isotonic fluid significantly decreased the risks of hyponatraemia at both $\leq 24 \mathrm{~h}\left(\mathrm{RR} 0.34 ; 95 \% \mathrm{CI}\right.$ : $\left.0.26-0.43 ; p<0.00001 ; I^{2}=0 \%\right)$ and $>24 \mathrm{~h}$ (RR $0.48 ; 95 \%$ CI: 0.36-0.64; $p<0.00001 ; I^{2}=0 \%$ ) (Figure 2 ). We found that the prevalence of hyponatraemia in the isotonic group is lower compared to the hypotonic group at both $\leq 24$ and $>24 \mathrm{~h} ; 5.7 \%$ (95\% CI: 3.7-7.6) and 6.0\% (95\% CI: $2.3-9.6)$, respectively (Figure 3 and Figure S2). Analysis on $0.9 \%$ vs. $0.18 \%$ sodium chloride and $0.9 \%$ vs. $0.45 \%$ sodium chloride revealed comparable relative risks in the development of hyponatraemia; RR 0.40 (95\% CI: 0.26-0.60; $p<0.0001 ; I^{2}=0 \%$ ) and RR 0.31 (95\% CI: $0.22-0.44 ; p<0.00001$; $I^{2}=0 \%$ ), respectively (Figure S3).

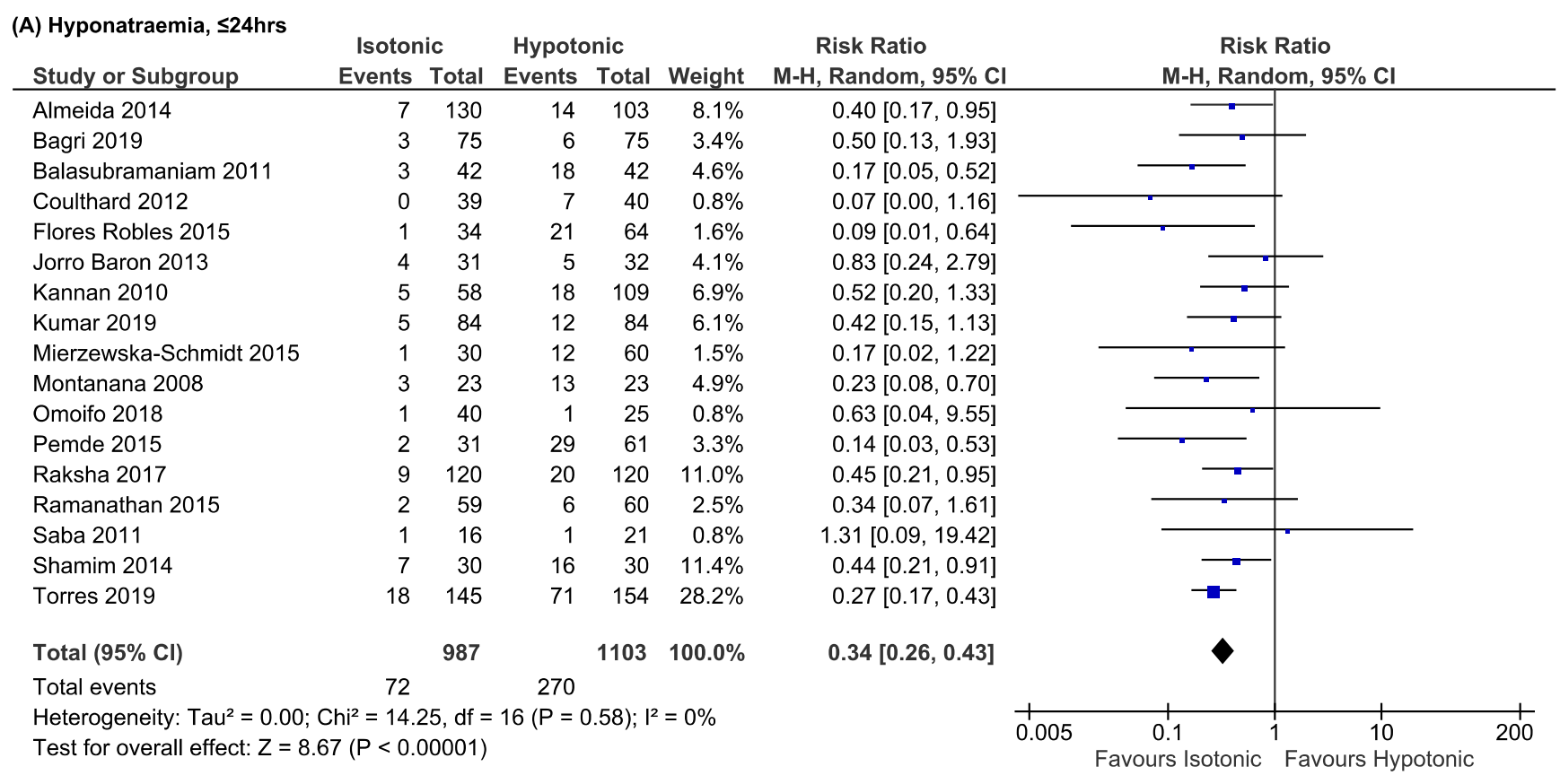

(B) Hyponatraemia, >24hrs

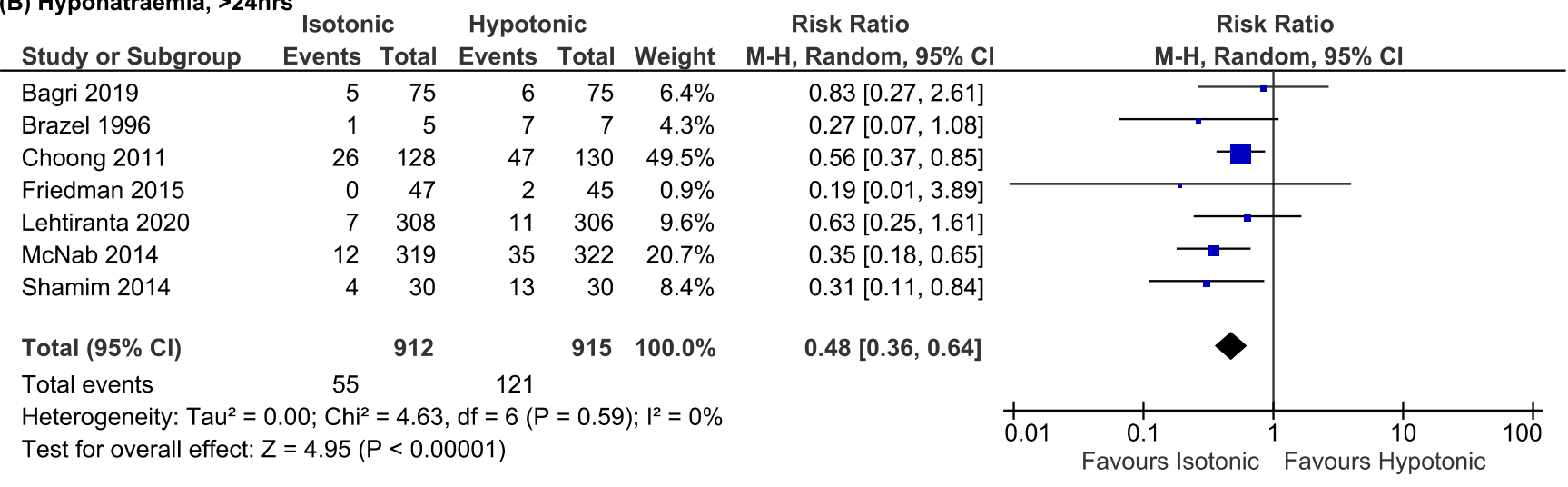

Figure 2. Cont. 
(C) Hypernatraemia, $\leq 24 \mathrm{hrs}$

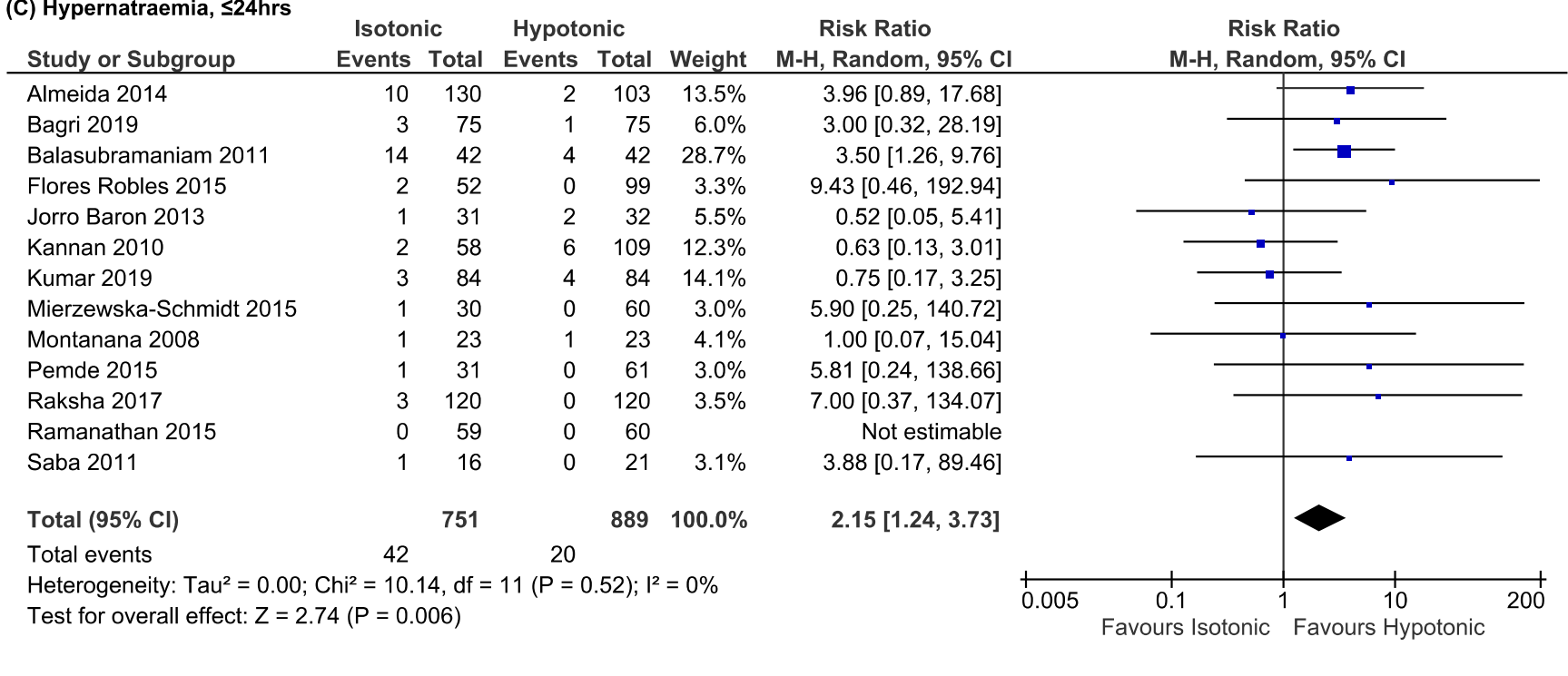

(D) Hypernatraemia, $>24 \mathrm{hrs}$

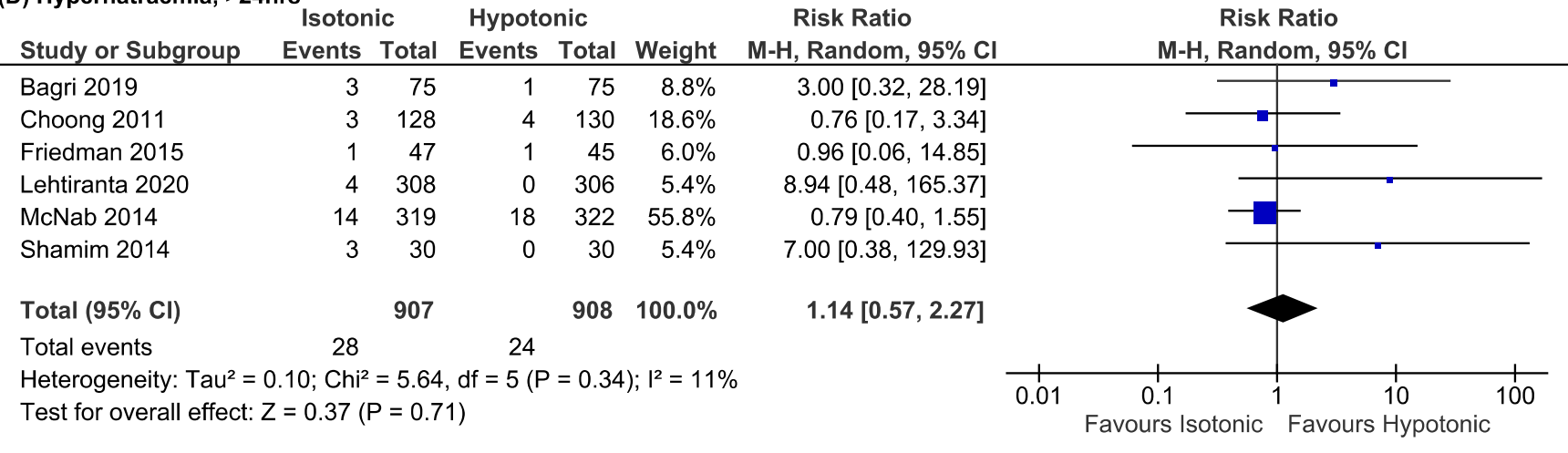

Figure 2. Risks of hyponatraemia (A,B) and hypernatraemia $(\mathbf{C}, \mathbf{D})$ following isotonic versus hypotonic fluid at $\leq 24$ and $>24 \mathrm{~h}$.

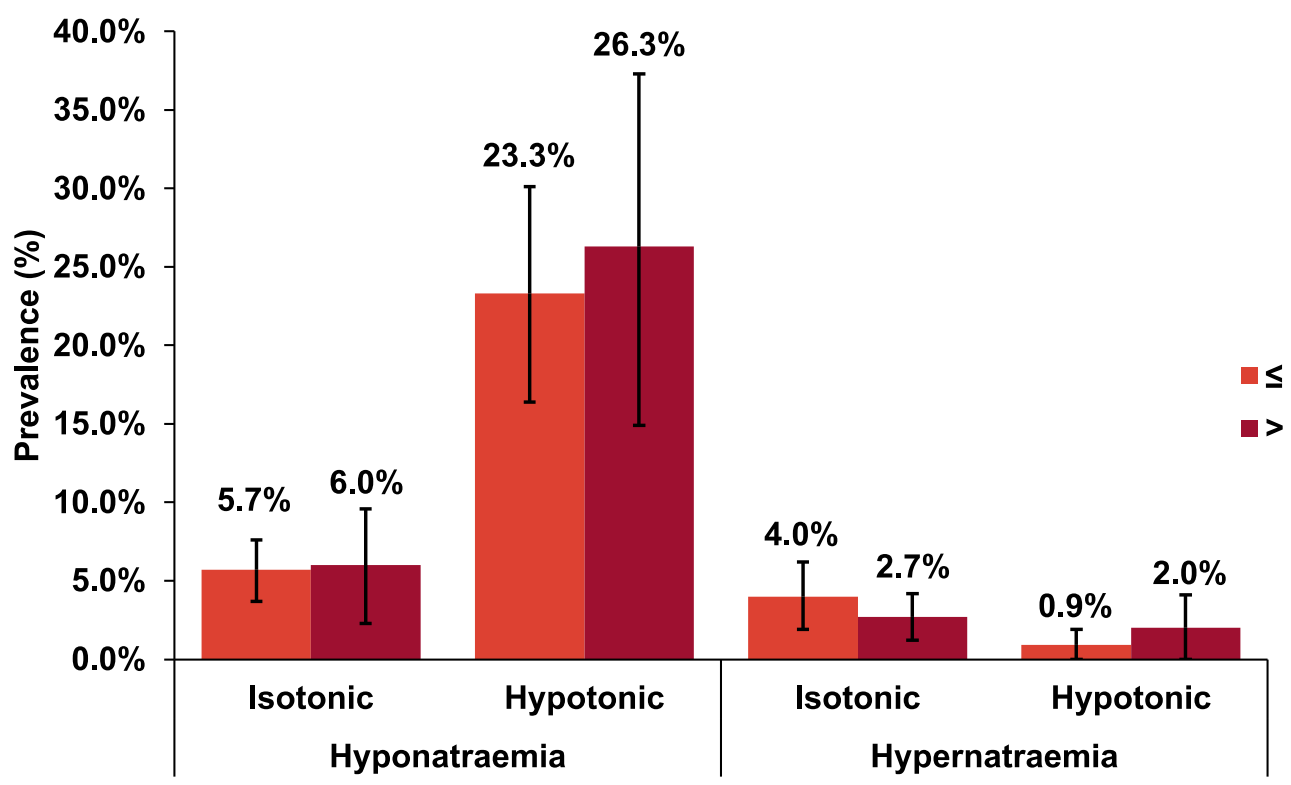

Figure 3. Prevalence with $95 \%$ CIs of hyponatraemia and hypernatraemia following isotonic and hypotonic fluids in hospitalised children at $\leq 24$ and $>24 \mathrm{~h}$. 


\subsection{Secondary Outcomes}

Hypernatraemia was evaluated in $78.3 \%$ of our included studies. Isotonic fluid was shown to increase the risk of hypernatraemia at $\leq 24 \mathrm{~h}$ (RR $2.15 ; 95 \%$ CI: $1.24-3.73 ; p=0.006$; $I^{2}=0 \%$ ) (Figure 2). However, after $>24 \mathrm{~h}$ of IVF infusion, there was no statistically different risk of hypernatraemia when using isotonic or hypotonic fluid (RR 1.14; 95\% CI: 0.57-2.27; $p=0.71 ; I^{2}=11 \%$ ) (Figure 2). Prevalence of hypernatraemia is higher in the isotonic group at both outcome measurement times: $4.0 \%\left(95 \%\right.$ CI: $\left.1.9-6.2, p=<0.01 ; I^{2}=58 \%\right)$ and $2.7 \%$ (95\% CI: $1.2-4.2, p=0.14 ; I^{2}=39 \%$ ) (Figure 3 and Figure S2).

Mean serum sodium level was lower in those receiving hypotonic fluid (Figure S4). At $\leq 24 \mathrm{~h}$, there was a statistically significant decrease of $2.50 \mathrm{mEq} / \mathrm{L}$ (95\% CI: $1.53-3.46$, $\left.p=<0.00001 ; I^{2}=90 \%\right)$. In contrast, after $24 \mathrm{~h}$, the decrease was not statistically significant; $2.05 \mathrm{mEql} / \mathrm{L}$ (95\% CI: $-2.00-6.11, p=0.32 ; I^{2}=96 \%$ ).

Data on urine sodium were available for 1295 participants from five studies (28-32) (Figure S4). The analyses showed a statistically significant decrease in urine sodium in the hypotonic group with wide $95 \%$ CIs and substantial heterogeneity. There was a decrease of $45.05 \mathrm{mmol} / \mathrm{L}\left(95 \% \mathrm{CI}: 21.70-68.39 ; p=0.0002 ; \mathrm{I}^{2}=91 \%\right.$ ) at $\leq 24 \mathrm{~h}$ and $51.36 \mathrm{mmol} / \mathrm{L}$ (95\% CI: $24.73-77.99 ; p=0.0002 ; I^{2}=89 \%$ ) at $>24 \mathrm{~h}$ in the hypotonic group.

Since the difference in serum osmolarity and osmolality in humans is negligible (33), we pooled the results into the analysis. At $\leq 24$ and $>24 \mathrm{~h}$, serum osmolarity and osmolality were lower in the hypotonic group; 9.80 (95\% CI: 3.12-16.48; $\left.p=0.004 ; I^{2}=96 \%\right)$ and 11.76 (95\% CI: $-1.57-25.09 ; p=0.08 ; I^{2}=97 \%$ ), respectively (Figure S4).

Some adverse outcomes observed in the included studies were the incidence of seizure, oedema, hypertension, metabolic acidosis, encephalopathy, and death (Figure 4 and Figures S5 and S6). There is little evidence to say for sure that one fluid is more likely to cause serious harm compared to the other one as none of the results were statistically significant. The following are the outcomes of our analyses (Figure S6) for the risks of the development of adverse outcomes: seizure (RR 0.45 ; 95\% CI: 0.08-2.67), oedema (RR 1.41, 95\% CI: 0.81-2.46), hypertension (RR 0.90; 95\% CI: 0.42-1.93), metabolic acidosis (RR 1.26; 95\% CI: 0.84-1.90), encephalopathy (RR 0.67, 95\% CI: 0.11-3.92), and death (RR 1.48; 95\% CI: 0.72-3.06).

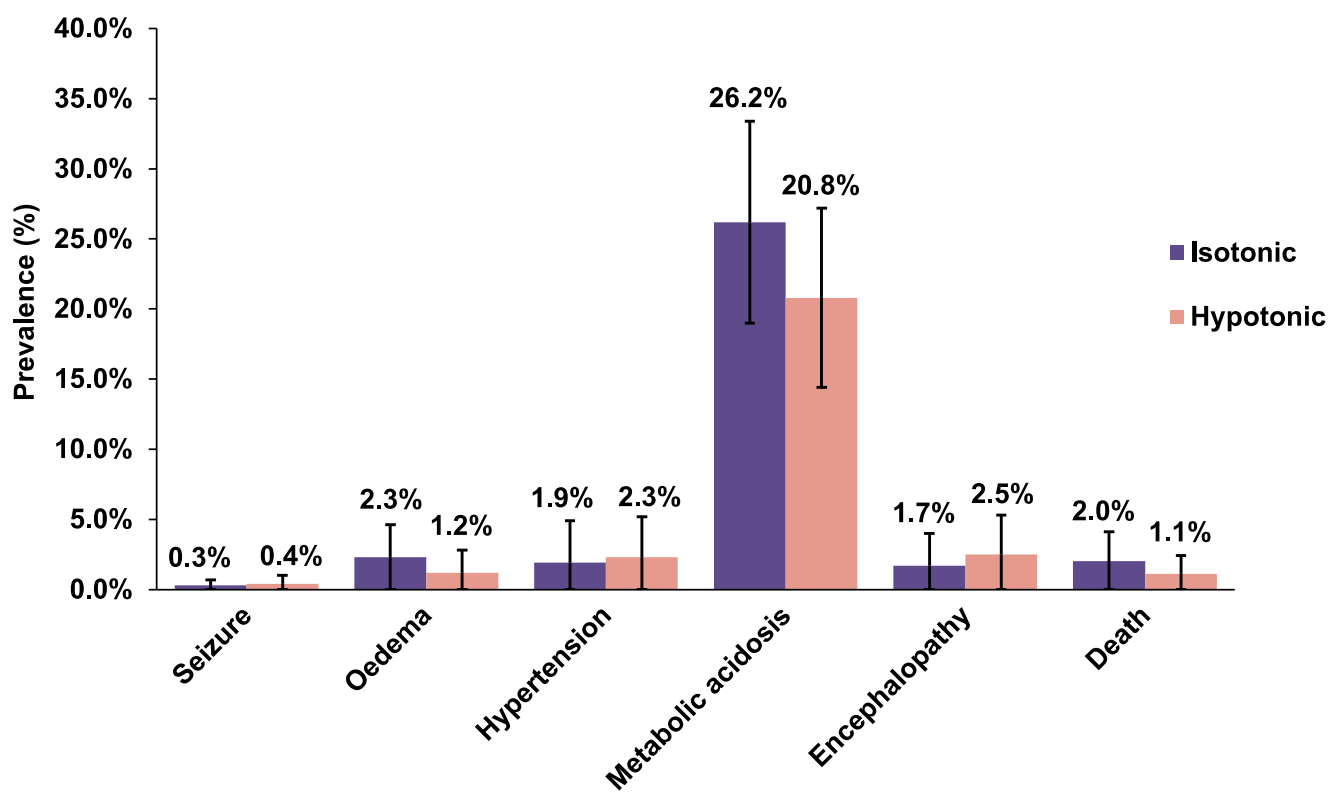

Figure 4. Prevalence with $95 \%$ CIs of adverse events following isotonic and hypotonic fluids in hospitalised children.

Figure 4 and Figure S5 outline the prevalence of each adverse outcome. The prevalence of seizure is similar in both isotonic and hypotonic groups, $0.3 \%$ (95\% CI: $0.0-0.7$ ) and $0.4 \%$ 
(95\% CI: 0.0-1.0), respectively. Oedema occurred in a total of 29 out of 724 patients in the isotonic group (2.3\%; $95 \%$ CI: $0.0-4.6)$ whereas 20 out of 771 patients developed oedema in the hypotonic group (1.2\%; 95\% CI: $0.0-2.8)$. The prevalence of hypertension was lower in the isotonic group $(1.9 \%$; $95 \%$ CI: $0.0-4.9)$ compared to the hypotonic group $(2.3 \%$; $95 \%$ CI: 0.0-5.2). As for the prevalence of metabolic acidosis, it was almost similar in both isotonic and hypotonic groups; $26.2 \%$ (95\% CI: 19-33.4) versus $20.8 \%$ (95\% CI: $14.4-27.2)$. Encephalopathy was seen in $1.7 \%$ (95\% CI: $0.0-4.0)$ of the participants in the isotonic group, while 2.5\% (95\% CI: 0.0-5.3) of the participants had encephalopathy in the hypotonic group. The prevalence of death was higher in the isotonic group, $2.0 \%$ (95\% CI: 0.0-4.1) compared to $1.1 \%$ (95\% CI: $0.0-2.4)$ in the hypotonic group.

A summary of the sensitivity analyses can be found in Table S2, where we observed that by excluding small studies $(n<100)$, excluding low- or medium-quality studies, using a fixed-effects model or excluding studies with a change of maintenance fluid did not change any of the results (hyponatremia, hypernatraemia, serum sodium levels or urine sodium levels at $24 \mathrm{~h}$ ) remarkably.

\subsection{Quality Assessment and Publication Bias}

Table S3 shows the quality assessment of all 22 studies. Based on our assessment, $77.3 \%(n=17)$ of the included studies were of high quality (low risk of bias) while the rest, $22.7 \%(n=5)$ were of moderate quality (moderate risk of bias). None of the included studies were classified as low quality (high risk of bias). Visual representation of the funnel plots along with the Egger's tests depicted the existence of significant publication bias (Figure 5 and Figure S7).

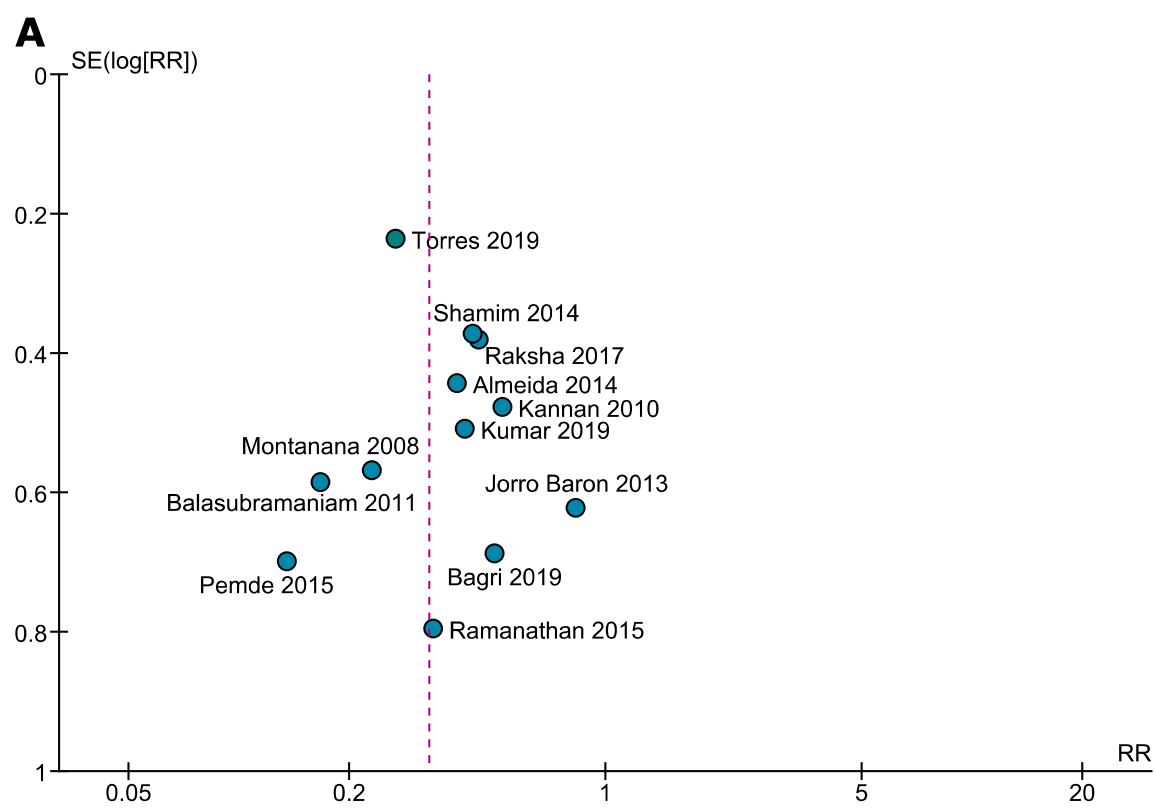

Figure 5. Cont. 
B

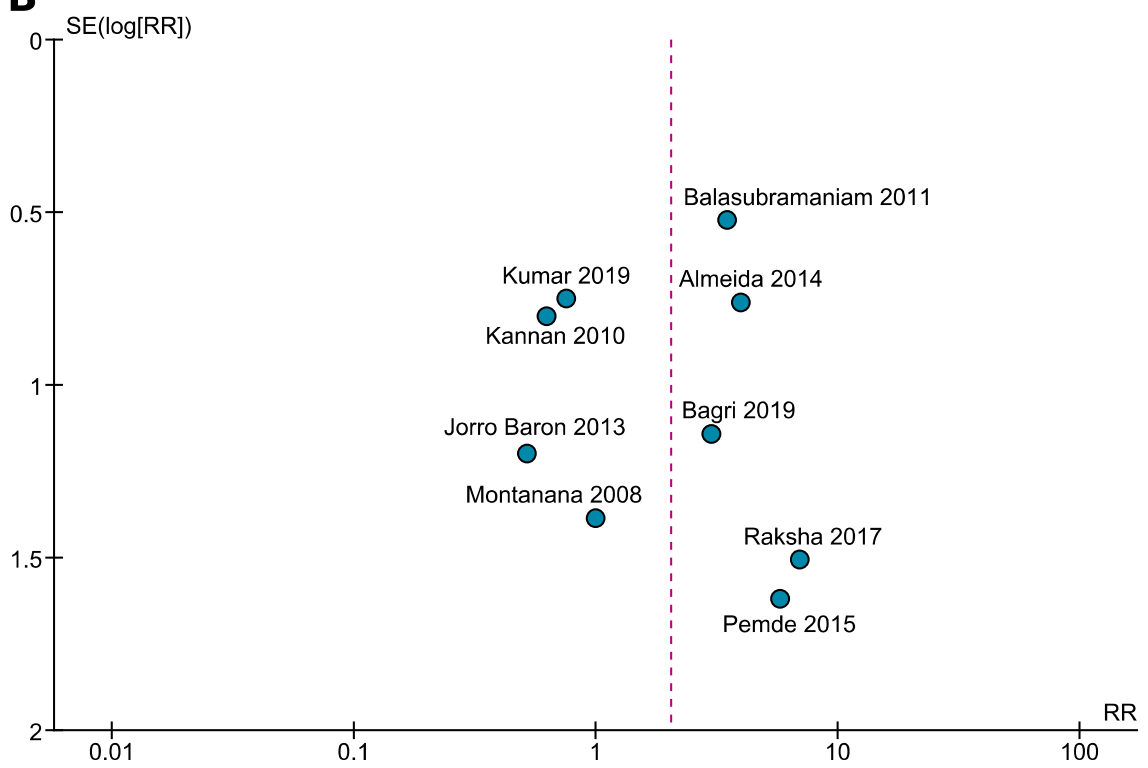

Figure 5. Funnel plots visually representing publication bias assessing risk ratio of (A) hyponatraemia and (B) hypernatraemia.

\section{Discussion}

The outcomes of our meta-analysis revealed that isotonic fluid protects children receiving IVF from developing hyponatraemia. Isotonic solutions do not theoretically expand the ICF compartment, thus, preserving the cellular structure and integrity [62]. This is especially important in the paediatric population as they have a higher brain to intracranial volume ratio [2], rendering them more vulnerable to developing complications such as cerebral oedema compared to adults. Therefore, physicians must exercise extreme caution when prescribing IVF in children to avoid unintended complications.

Hospital-acquired hyponatraemia is entirely preventable. Although in our included studies, an assortment of hypotonic fluids was used, the outcome of each included study was comparable indicating that any type of hypotonic fluid, i.e., $0.45 \%$ or $0.18 \%$ will increase the risk of iatrogenic hyponatraemia. We found no evidence that one hypotonic solution is more likely than the other to cause hyponatraemia (Figure S3), hence any type of hypotonic fluid should generally be avoided. We also discovered that isotonic fluid is consistently protective against hyponatraemia at $8,12,18,24,36,48$, and $72 \mathrm{~h}$. This means that isotonic fluid is a safer choice till at least $72 \mathrm{~h}$ of treatment. Further research is needed to study the effect of fluid on sodium balance in children when it is used for longer duration.

Holliday et al. [63] proposed that isotonic solution increases sodium load when its use is prolonged. Our findings, however, do not support this hypothesis. This is in line with previous studies [64-69]. Our data demonstrated that after $24 \mathrm{~h}$, there is no significant difference in the risk of developing hypernatraemia. Thus, there should be no reservations in using isotonic solutions as maintenance fluid. However, a child may not require parenteral fluid supplementation for a prolonged period. The duration of fluid therapy depends on the reason for admission [70]. This makes studying the long-term effect of IVF on the occurrence of hypernatraemia challenging. Nevertheless, this should never take away a physician's clinical judgment. Fluid supplementation should always be adjusted to the needs of the child and assessed regularly, particularly in critically ill children [71]. This is the only means to ensure that unfavourable events are avoided.

In our investigation, the hypotonic group had lower mean serum and urinary sodium, as well as lower serum osmolarity/osmolality. As the fluid is provided for a longer period, the mean difference in sodium level lessens, which makes sense because a child likely 
to improve with therapy, resulting in fewer non-osmotic ADH stimuli and hence less free-water retention. It is unclear if the duration of fluid therapy will directly affect the mean sodium level, i.e., longer fluid therapy will result in lower serum sodium level, but we can conclude that hypotonic fluid will cause a fall in sodium levels. This is especially important in patients suffering from chronic diseases like cirrhosis or nephrotic syndrome where hypervolemic hyponatraemia is likely already present. Few studies looked at urine sodium and serum osmolarity/osmolality, making inferences on the impact of solution types on these variables challenging. Nonetheless, our findings indicated that hypotonic fluid lowers serum osmolarity/osmolality, which is understandable given that it provides electrolyte-free water.

The persistent non-osmotic ADH stimuli that a child experiences may explain why hyponatraemia persists even after $72 \mathrm{~h}$ of treatment (Figure S1). Hyponatraemia results from the kidney's inability to excrete free-water or excessive water intake [72]. This is influenced by the thirst mechanism which is activated as plasma osmolality increases. However, in hospitalised individuals, euvolemic hyponatraemia usually occurs because of sustained $\mathrm{ADH}$ release in the absence of appropriate osmotic stimulus such as raised plasma osmolality [73].

ADH plays an immense role in sodium homeostasis as described previously. It can promote hyponatraemia by increasing the permeability of collecting ducts in the nephron, consequently causing the retention of free water. Hospitalised children are more likely to develop hyponatraemia, which inhibits their ability to excrete free-water due to numerous non-osmotic ADH secretion triggers such as pain, stress, dehydration, and post-operative effects [74]. Furthermore, when maintenance fluid is prescribed, the IVF supplementation is determined by the physician, not the patients. Not many studies have included ADH measurement as an outcome. Choong et al. [45], Coulthard et al. [46], and Kannan et al. [40] reported serum ADH levels after infusion of IVF. However, the data was not normally distributed; hence, we could not carry out additional analysis. The serum ADH levels in all three studies were elevated, but the results did not differ significantly between the treatment arms. As neither the physician nor the patient can control ADH secretion, all fluid prescribers must be aware of the impact ADH secretion has on a patient's fluid balance.

Despite the fact that patients receiving isotonic fluid have about $50 \%$ higher mortality rate during their stay, a comprehensive evaluation of the causes of mortality found that they had nothing to do with sodium levels. Kannan et al. [40] reported one death (1.7\%) in the isotonic group. The cause of death was acute respiratory distress syndrome, and the patient was normonatraemic throughout the study period. On the other hand, JorroBaron et al. [49] found three deaths (9.4\%) in the hypotonic group. The cause of death was unrelated to the maintenance fluid infusion. All three patients had serum sodium above $130 \mathrm{mmol} / \mathrm{L}$ throughout the study. Only one study, Ramanathan et al. [57], reported death $(n=2)$ associated with severe hyponatraemia (serum sodium $<125 \mathrm{mmol} / \mathrm{L}$ ) in the hypotonic group. However, the causes of death were attributed to respiratory failure. Bagri et al. [42] and Raksha et al. [58] reported deaths in both treatment arms. The patients were nomonatraemic in Rasksha's study.

From our investigation, we observed that none of the fluids increased the risks of adverse events significantly. Most studies had safety restrictions integrated into their methodology to safeguard against serious adverse outcomes. For instance, in Choong et al. [45], the initial methodology was fully blinded; however, during the study, 24 out of 258 patients $(9.3 \%)$ were modified to open-label maintenance fluid. The most common reason for the change was hyponatraemia. Although these safety measures may not reveal the actual effects of isotonic versus hypotonic fluid in the development of adverse outcomes, it is unethical to continue administering the fluid to patients or to refuse to intervene when it is apparent that it is causing harm. Moreover, only $15(68.2 \%)$ of the included studies reported adverse outcomes and less than 10 studies have data available for each adverse outcome we were looking at. With this small number of reported data, this potentially does not depict the true risks and prevalence of adverse outcome associated with IVF. 
While our analysis showed that hyponatraemia does not directly cause mortality or morbidity, it has been well documented that hyponatraemia is strongly associated with increased risks of death and adverse events [75-77]. This causal relationship has also been exhibited in the adult population [78]. Since our research has demonstrated that hypotonic fluid is related to hyponatraemia, it is advisable to avoid using hypotonic fluid as maintenance IVF. Still, we encourage physicians to carefully monitor and observe their patients during IVF therapy [79].

Another criticism against the use of isotonic solutions is the development of metabolic acidosis attributed to the excess chloride administration. One study specifically looking into this outcome was included in our analysis. In a study conducted by Torres et al. [61], there were no significant differences in the incidence of metabolic acidosis between the two treatment arms (Figure 4 and Figure S5). Other studies have found that isotonic fluid causes metabolic acidosis, but many of them involved rapid fluid infusion [80-85]. In a retrospective cohort study conducted by Bulfon et al., they have found that when $0.9 \%$ sodium chloride is used as both bolus and maintenance fluid, there is an increased risk of developing hyperchloraemic metabolic acidosis (HCMA). However, when used only as maintenance fluid, $0.9 \%$ sodium chloride was not an independent risk factor for the occurrence of HCMA [86]. A study examining the effect of isotonic solution as a maintenance IVF on the development of metabolic acidosis, specifically in children, is needed to validate this point.

We performed a thorough search strategy in accordance with the PRISMA guideline and excluded studies in which patients had hyponatraemia prior to the infusion of the study fluid. We also looked at the risks of hyponatraemia at various time points, which revealed that hyponatraemia can occur as early as $6 \mathrm{~h}$ when hypotonic fluid is used and can last up to at least $72 \mathrm{~h}$. Apart from that, we performed a subgroup analysis looking at data on $0.9 \%$ versus $0.45 \%$ and $0.9 \%$ versus $0.18 \%$ sodium chloride at $24 \mathrm{~h}$ (Figure S3). Furthermore, none of the research included was of poor quality. To the best of our knowledge, this is the only meta-analysis that examined the risks and prevalence of hypo and hypernatraemia at both $\leq 24$ and $>24 \mathrm{~h}$ in hospitalised children. In addition, from our sensitivity analysis, we found that results did not change remarkably, representing the robustness and reliability of our findings.

Only published studies were considered. A variety of fluids were also used in the included studies. This could explain the significant heterogeneity observed in the analysis of the continuous data. Our research included both surgical and medical patients. As these two groups of patients are likely to be exposed to different non-osmotic ADH triggers, the risk of hyponatraemia may not be the same in all hospitalised children. We could not investigate the impact of infusion rate because there was insufficient data. One study, however, found that fluid restriction does not reduce the risk of hyponatraemia [87]. One of the studies included [40] compared isotonic fluid to hypotonic fluid at maintenance rates and hypotonic fluid at limited rates in a three-arm trial. Three other papers $[47,53,56]$ compared isotonic fluid with two types of hypotonic fluids. We combined the data from the hypotonic treatment arm in our analysis. As the fluids' compositions are dissimilar, this may introduce bias. We also included one study conducted on neonates [43], however, as their renal handing of fluid and electrolytes are likely to be different to the other population in our study $[88,89]$, our analysis may not be applicable to this age group. Nonetheless, other published studies have also shown that hypotonic fluid is associated with decreases in serum sodium levels in this population [90].

\section{Conclusions}

Current evidence supports the use of isotonic solution as maintenance IVF which could prevent iatrogenic hyponatraemia in hospitalised children and consequently avoid unfavourable incidents. However, because both isotonic and hypotonic fluids can cause hyponatraemia, fluid prescription should always be tailored to the specific needs of each child. According to our findings, the risk of adverse events is not substantially different be- 
tween the two fluids; nevertheless, maintenance IVF should always be prescribed with care.

Supplementary Materials: The following are available online at https:/ / www.mdpi.com/article / 10.3390/children8090785/s1, Table S1: Database search strategies, Table S2: Sensitivity analyses, Table S3: Quality assessment of the included studies, Figure S1: Risk of developing hyponatraemia followed by isotonic vs. hypotonic fluids in hospitalised children, Figure S2: Prevalence of hyponatraemia $(\mathrm{A}, \mathrm{B})$ and hypernatraemia $(\mathrm{C}, \mathrm{D})$ following isotonic and hypotonic fluids in hospitalised children at $\leq 24$ and $>24 \mathrm{~h}$, Figure S3: Risk of developing hyponatraemia followed by isotonic $(0.9 \%)$ vs. hypotonic fluids $(0.18 \%$ or $0.45 \%)$ in hospitalised children, Figure S4: Mean differences of serum sodium levels $(A, B)$, urine sodium $(C, D)$, and serum osmolarity/osmolality $(E, F)$ following isotonic and hypotonic fluids in hospitalised children at $\leq 24$ and $>24 \mathrm{~h}$, Figure S5: Prevalence of adverse events following isotonic and hypotonic fluids in hospitalised children, Figure S6: Risk of adverse events following isotonic and hypotonic fluids in hospitalised children, Figure S7: Funnel plots representing significant publication bias in estimating the prevalence of hyponatraemia followed by (A) isotonic and (B) hypotonic fluids and hypernatraemia followed by (C) isotonic and (D) hypotonic fluids.

Author Contributions: Conceptualisation, M.A.A.B. and M.A.I.; methodology, N.H. and M.A.I.; software, N.H. and M.A.I.; validation, M.A.I. and M.A.A.B.; formal analysis, N.H. and M.A.I.; investigation, N.H. and M.A.I.; resources, M.A.A.B. and M.A.I.; data curation, N.H., M.A.I. and M.A.A.B.; writing-original draft preparation, N.H.; writing-review and editing, M.A.I. and M.A.A.B.; visualisation, M.A.I.; supervision, M.A.A.B. and M.A.I.; project administration, M.A.A.B. and M.A.I.; funding acquisition, M.A.I. All authors have read and agreed to the published version of the manuscript.

Funding: The APC was funded by the Research Creativity and Management (RCMO), Universiti Sains Malaysia (USM) and the School of Medical Sciences, USM.

Institutional Review Board Statement: Not applicable.

Informed Consent Statement: Not applicable.

Data Availability Statement: The data presented in this study are available within the article and Supplementary Materials.

Conflicts of Interest: The authors declare no conflict of interest.

\section{References}

1. Holliday, M.A.; Segar, W.E. The maintenance need for water in parenteral fluid therapy. Pediatrics 1957, 19, 823-832. [CrossRef] [PubMed]

2. Friedman, J.N. Risk of acute hyponatremia in hospitalized children and youth receiving maintenance intravenous fluids. Paediatr. Child Health 2013, 18, 102-107. [CrossRef]

3. Moritz, M.L.; Ayus, J.C. Prevention of hospital-acquired hyponatremia: A case for using isotonic saline. Pediatrics 2003, 111, 227-230. [CrossRef] [PubMed]

4. National Institute for Health and Care Excellence. Intravenous Fluid Therapy in Adults in Hospital; National Institute for Health and Care Excellence: London, UK, 2017.

5. Feld, L.G.; Neuspiel, D.R.; Foster, B.A.; Leu, M.G.; Garber, M.D.; Austin, K.; Basu, R.K.; Conway, E.E., Jr.; Fehr, J.J.; Hawkins, C.; et al. Clinical Practice Guideline: Maintenance Intravenous Fluids in Children. Pediatrics 2018, 142, 1-12. [CrossRef]

6. Mathur, A.; Johnston, G.; Clark, L. Improving intravenous fluid prescribing. J. R. Coll. Physicians Edinb. 2020, 50, 181-187. [CrossRef]

7. Hall, A.M.; Ayus, J.C.; Moritz, M.L. Things We Do For No Reason: The Default Use of Hypotonic Maintenance Intravenous Fluids in Pediatrics. J. Hosp. Med. 2018, 13, 637-640. [CrossRef] [PubMed]

8. McNab, S. Intravenous maintenance fluid therapy in children. J. Paediatr. Child Health 2016, 52, 137-140. [CrossRef] [PubMed]

9. Moritz, M.L.; Ayus, J.C. Maintenance intravenous fluids in acutely ill patients. N. Engl. J. Med. 2015, 373, 1350-1360. [CrossRef] [PubMed]

10. Severs, D.; Hoorn, E.J.; Rookmaaker, M.B. A critical appraisal of intravenous fluids: From the physiological basis to clinical evidence. Nephrol. Dial. Transplant. 2015, 30, 178-187. [CrossRef] [PubMed]

11. Ghosh, A.; Maltez, C. Intravenous fluid prescribing for medical inpatients: Are we getting it right? Clin. Med. 2019, 19, 57. [CrossRef]

12. Lobo, D.; Dube, M.; Neal, K.; Simpson, J.; Rowlands, B.; Allison, S. Problems with solutions: Drowning in the brine of an inadequate knowledge base. Clin. Nutr. 2001, 20, 125-130. [CrossRef] [PubMed] 
13. Ramsay, G.; Baggaley, A.; Shaw, P.V.; Soltanmohammadi, E.; Ventham, N.; Shi, N.G.; Pearson, R.; Knight, S.; Forde, C.; Moore, N. Variability in the prescribing of intravenous fluids: A cross sectional multicentre analysis of clinical practice. Int. J. Surg. 2018, 51, 199-204. [CrossRef]

14. Steele, A.; Gowrishankar, M.; Abrahamson, S.; Mazer, C.D.; Feldman, R.D.; Halperin, M.L. Postoperative hyponatremia despite near-isotonic saline infusion: A phenomenon of desalination. Ann. Intern. Med. 1997, 126, 20-25. [CrossRef]

15. Alvis-Miranda, H.R.; Castellar-Leones, S.M.; Moscote-Salazar, L.R. Intravenous Fluid Therapy in Traumatic Brain Injury and Decompressive Craniectomy. Bull. Emerg. Trauma 2014, 2, 3-14.

16. Tommasino, C.; Picozzi, V. Volume and electrolyte management. Best Pract. Res. Clin. Anaesthesiol. 2007, 21, 497-516. [CrossRef] [PubMed]

17. Bockenhauer, D.; Aitkenhead, H. The kidney speaks: Interpreting urinary sodium and osmolality. Arch. Dis. Child. Educ. Pract. Ed. 2011, 96, 223-227. [CrossRef] [PubMed]

18. Kamel, K.S.; Ethier, J.H.; Richardson, R.M.; Bear, R.A.; Halperin, M.L. Urine electrolytes and osmolality: When and how to use them. Am. J. Nephrol. 1990, 10, 89-102. [CrossRef]

19. Braun, M.M.; Barstow, C.; Pyzocha, N. Diagnosis and management of sodium disorders: Hyponatremia and hypernatremia. Am. Fam. Physician 2015, 91, 299-307.

20. Yeates, K.E.; Singer, M.; Morton, A.R. Salt and water: A simple approach to hyponatremia. CMAJ 2004, 170, 365-369. [PubMed]

21. Goh, K.P. Management of hyponatremia. Am. Fam. Physician 2004, 69, 2387-2394.

22. National Institute for Health and Care Excellence. Intravenous Fluid Therapy in Children and Young People in Hospital; National Institute for Health and Care Excellence: London, UK, 2020. Available online: https://www.ncbi.nlm.nih.gov/books/NBK56344 9/ (accessed on 11 June 2020).

23. Kinlin, L.M.; Helmers, A.J.; Friedman, J.N.; Beck, C.E. Choice of maintenance intravenous fluids among paediatric residents in Canada. Paediatr. Child Health 2020, 25, 518-524. [CrossRef]

24. Hall, A.M.; Ayus, J.C.; Moritz, M.L. How Salty Are Your Fluids? Pediatric Maintenance IV Fluid Prescribing Practices Among Hospitalists. Front. Pediatr. 2019, 7, 549. [CrossRef] [PubMed]

25. Davies, P.; Hall, T.; Ali, T.; Lakhoo, K. Intravenous postoperative fluid prescriptions for children: A survey of practice. BMC Surg. 2008, 8, 10. [CrossRef]

26. Freeman, M.A.; Ayus, J.C.; Moritz, M.L. Maintenance intravenous fluid prescribing practices among paediatric residents. Acta Paediatr. 2012, 101, 465-468. [CrossRef]

27. Lee, J.M.; Jung, Y.; Lee, S.E.; Lee, J.H.; Kim, K.H.; Koo, J.W.; Park, Y.S.; Cheong, H.I.; Ha, I.-S.; Choi, Y.; et al. Intravenous fluid prescription practices among pediatric residents in Korea. Korean J. Pediatr. 2013, 56, 282-285. [CrossRef]

28. Way, C.; Dhamrait, R.; Wade, A.; Walker, I. Perioperative fluid therapy in children: A survey of current prescribing practice. Br. J. Anaesth. 2006, 97, 371-379. [CrossRef] [PubMed]

29. Shukla, S.; Basu, S.; Moritz, M.L. Use of hypotonic maintenance intravenous fluids and hospital-acquired hyponatremia remain common in children admitted to a general pediatric ward. Front. Pediatr. 2016, 4, 90. [CrossRef] [PubMed]

30. Nordstrom, M.; Landman, G.; Pfaff, N.; Kaiser, S.V. Improving Isotonic Maintenance Intravenous Fluid Use at a Tertiary Children's Hospital. Hosp. Pediatr. 2021, 11, 374-379. [CrossRef]

31. Akinsola, B.; Cheng, J.; Iyer, S.B.; Jain, S. Improving Isotonic Maintenance Intravenous Fluid Use in the Emergency Department. Pediatrics 2021, 148, e2020022947. [CrossRef]

32. Moritz, M.L.; Ayus, J.C. Isotonic fluids prevent hospital-acquired hyponatraemia. Nat. Rev. Nephrol. 2015, 11, 202-203. [CrossRef] [PubMed]

33. Kannan, L.; Lodha, R. Appropriate fluid for intravenous maintenance therapy in hospitalized children-current status. Indian J. Pediatr. 2011, 78, 357-359. [CrossRef] [PubMed]

34. Page, M.J.; Moher, D.; Bossuyt, P.M.; Boutron, I.; Hoffmann, T.C.; Mulrow, C.D.; Shamseer, L.; Tetzlaff, J.M.; Akl, E.A.; Brennan, S.E. PRISMA 2020 explanation and elaboration: Updated guidance and exemplars for reporting systematic reviews. BMJ 2021, $372,1-36$.

35. Varrier, M.; Ostermann, M. Fluid Composition and Clinical Effects. Crit. Care Clin. 2015, 31, 823-837. [CrossRef]

36. Saniasiaya, J.; Islam, M.A.; Abdullah, B. Prevalence and characteristics of taste disorders in cases of COVID-19: A meta-analysis of 29,349 patients. Otolaryngol. Head Neck Surg. 2020, 165, 33-42. [CrossRef] [PubMed]

37. Islam, M.A.; Alam, S.S.; Kundu, S.; Hossan, T.; Kamal, M.A.; Cavestro, C. Prevalence of Headache in Patients With Coronavirus Disease 2019 (COVID-19): A Systematic Review and Meta-Analysis of 14,275 Patients. Front. Neurol. 2020, 11, 562634. [CrossRef] [PubMed]

38. Moola, S.; Munn, Z.; Tufanaru, C.; Aromataris, E.; Sears, K.; Sfetcu, R.; Currie, M.; Lisy, K.; Qureshi, R.; Mattis, P.; et al. Chapter 7: Systematic reviews of etiology and risk. In JBI Manual for Evidence Synthesis; Aromataris, E., Munn, Z., Eds.; JBI: Adelaide, Australia, 2020.

39. Hajissa, K.; Marzan, M.; Idriss, M.I.; Islam, M.A. Prevalence of Drug-Resistant Tuberculosis in Sudan: A Systematic Review and Meta-Analysis. Antibiotics 2021, 10, 932. [CrossRef]

40. Kannan, L.; Lodha, R.; Vivekanandhan, S.; Bagga, A.; Kabra, S.K.; Kabra, M. Intravenous fluid regimen and hyponatraemia among children: A randomized controlled trial. Pediatr. Nephrol. 2010, 25, 2303-2309. [CrossRef] [PubMed] 
41. Almeida, H.I.; Mascarenhas, M.I.; Loureiro, H.C.; Abadesso, C.S.; Nunes, P.S.; Moniz, M.S.; Machado, M.C. The effect of NaCl $0.9 \%$ and $\mathrm{NaCl} 0.45 \%$ on sodium, chloride, and acid-base balance in a PICU population. J. Pediatr. 2015, 91, 499-505. [CrossRef]

42. Bagri, N.K.; Saurabh, V.K.; Basu, S.; Kumar, A. Isotonic versus Hypotonic Intravenous Maintenance Fluids in Children: A Randomized Controlled Trial. Indian J. Pediatr. 2019, 86, 1011-1016. [CrossRef]

43. Balasubramaniam, K.; Kumar, P.; Saini, S.S.; Attri, S.V.; Dutta, S. Isotonic versus hypotonic fluid supplementation in term neonates with severe hyperbilirubinemia-A double-blind, randomized, controlled trial. Acta Paediatr. 2012, 101, 236-241. [CrossRef] [PubMed]

44. Brazel, P.W.; McPhee, I.B. Inappropriate secretion of antidiuretic hormone in postoperative scoliosis patients: The role of fluid management. Spine 1996, 21, 724-727. [CrossRef] [PubMed]

45. Choong, K.; Arora, S.; Cheng, J.; Farrokhyar, F.; Reddy, D.; Thabane, L.; Walton, J.M. Hypotonic versus isotonic maintenance fluids after surgery for children: A randomized controlled trial. Pediatrics 2011, 128, 857-866. [CrossRef] [PubMed]

46. Coulthard, M.G.; Long, D.A.; Ullman, A.J.; Ware, R.S. A randomised controlled trial of Hartmann's solution versus half normal saline in postoperative paediatric spinal instrumentation and craniotomy patients. Arch. Dis. Child. 2012, 97, 491-496. [CrossRef] [PubMed]

47. Flores Robles, C.M.; Cuello García, C.A. A prospective trial comparing isotonic with hypotonic maintenance fluids for prevention of hospital-acquired hyponatraemia. Paediatr. Int. Child Health 2016, 36, 168-174. [CrossRef] [PubMed]

48. Friedman, J.N.; Beck, C.E.; DeGroot, J.; Geary, D.F.; Sklansky, D.J.; Freedman, S.B. Comparison of isotonic and hypotonic intravenous maintenance fluids: A randomized clinical trial. JAMA Pediatr. 2015, 169, 445-451. [CrossRef] [PubMed]

49. Baron, F.; Meregalli, C.N.; Rombola, V.; Bolasell, C.; Pigliapoco, V.; Bartoletti, S.; Debaisi, G. Hypotonic versus isotonic intravenous maintenance fluids in critically ill pediatric patients: A randomized clinical trial. Arch. Argent. Pediatr. 2013, 111, $281-287$. [CrossRef]

50. Kumar, M.; Mitra, K.; Jain, R. Isotonic versus hypotonic saline as maintenance intravenous fluid therapy in children under 5 years of age admitted to general paediatric wards: A randomised controlled trial. Paediatr. Int. Child Health 2019, 40, 44-49. [CrossRef] [PubMed]

51. Lehtiranta, S.; Honkila, M.; Kallio, M.; Paalanne, N.; Peltoniemi, O.; Pokka, T.; Renko, M.; Tapiainen, T. Risk of electrolyte disorders in acutely ill children receiving commercially available plasmalike isotonic fluids: A randomized clinical trial. JAMA Pediatr. 2021, 175, 28-35. [CrossRef] [PubMed]

52. McNab, S.; Duke, T.; South, M.; Babl, F.E.; Lee, K.J.; Arnup, S.J.; Young, S.; Turner, H.; Davidson, A. 140 mmol/L of sodium versus $77 \mathrm{mmol} / \mathrm{L}$ of sodium in maintenance intravenous fluid therapy for children in hospital (PIMS): A randomised controlled double-blind trial. Lancet 2015, 385, 1190-1197. [CrossRef]

53. Mierzewska-Schmidt, M. Intraoperative fluid management in children-A comparison of three fluid regimens. Anaesthesiol. Intensive Ther. 2015, 47, 125-130. [CrossRef]

54. Montanana, P.A.; i Alapont, V.M.; Ocon, A.P.; Lopez, P.O.; Prats, J.L.L.; Parreño, J.D.T. The use of isotonic fluid as maintenance therapy prevents iatrogenic hyponatremia in pediatrics: A randomized, controlled open study. Pediatr. Crit. Care Med. 2008, 9 , 589-597. [CrossRef]

55. Omoifo, C.E.; Edomwonyi, N.P.; Idogun, S.E. Incidence of hyponatraemia following the use of three different intravenous fluids in paediatric surgery. Afr. J. Paediatr. Surg. 2018, 15, 69-72. [CrossRef] [PubMed]

56. Pemde, H.K.; Dutta, A.K.; Sodani, R.; Mishra, K. Isotonic intravenous maintenance fluid reduces hospital acquired hyponatremia in young children with central nervous system infections. Indian J. Pediatr. 2015, 82, 13-18. [CrossRef]

57. Ramanathan, S.; Kumar, P.; Mishra, K.; Dutta, A.K. Isotonic versus Hypotonic Parenteral Maintenance Fluids in Very Severe Pneumonia. Indian J. Pediatr. 2016, 83, 27-32. [CrossRef]

58. Raksha, S.; Dakshayani, B. Full Volume Isotonic (0.9\%) vs. Two-Thirds Volume Hypotonic $(0.18 \%)$ Intravenous Maintenance Fluids in Preventing Hyponatremia in Children Admitted to Pediatric Intensive Care Unit—A Randomized Controlled Study. J. Trop. Pediatr. 2017, 63, 454-460.

59. Saba, T.G.; Fairbairn, J.; Houghton, F.; Laforte, D.; Foster, B.J. A randomized controlled trial of isotonic versus hypotonic maintenance intravenous fluids in hospitalized children. BMC Pediatr. 2011, 11, 82. [CrossRef] [PubMed]

60. Shamim, A.; Afzal, K.; Ali, S.M. Safety and efficacy of isotonic $(0.9 \%)$ vs. hypotonic $(0.18 \%)$ saline as maintenance intravenous fluids in children: A randomized controlled trial. Indian Pediatr. 2014, 51, 969-974. [CrossRef]

61. Torres, S.F.; Iolster, T.; Schnitzler, E.J.; Serrate, A.J.S.; Sticco, N.A.; Rivarola, M.R. Hypotonic and isotonic intravenous maintenance fluids in hospitalised paediatric patients: A randomised controlled trial. BMJ Paediatr. Open 2019, 3, 1-6. [CrossRef] [PubMed]

62. Taylor, D.; Durward, A. Pouring salt on troubled waters. Arch. Dis. Child. 2004, 89, 411-414. [CrossRef] [PubMed]

63. Holliday, M.A.; Ray, P.E.; Friedman, A.L. Fluid therapy for children: Facts, fashions and questions. Arch. Dis. Child. 2007, 92, 546-550. [CrossRef]

64. Choong, K.; Kho, M.E.; Menon, K.; Bohn, D. Hypotonic versus isotonic saline in hospitalised children: A systematic review. Arch. Dis. Child. 2006, 91, 828-835. [CrossRef]

65. Foster, B.A.; Tom, D.; Hill, V. Hypotonic versus isotonic fluids in hospitalized children: A systematic review and meta-analysis. J. Pediatr. 2014, 165, 163-169. [CrossRef]

66. McNab, S.; Ware, R.S.; Neville, K.A.; Choong, K.; Coulthard, M.G.; Duke, T.; Davidson, A.; Dorofaeff, T. Isotonic versus hypotonic solutions for maintenance intravenous fluid administration in children. Cochrane Database Syst. Rev. 2014. [CrossRef] [PubMed] 
67. Padua, A.P.; Macaraya, J.R.G.; Dans, L.F.; Anacleto, F.E. Isotonic versus hypotonic saline solution for maintenance intravenous fluid therapy in children: A systematic review. Pediatr. Nephrol. 2015, 30, 1163-1172. [CrossRef] [PubMed]

68. Yang, G.; Jiang, W.; Wang, X.; Liu, W. The efficacy of isotonic and hypotonic intravenous maintenance fluid for pediatric patients: A meta-analysis of randomized controlled trials. Pediatr. Emerg. Care 2015, 31, 122-126. [CrossRef] [PubMed]

69. Wang, J.; Xu, E.; Xiao, Y. Isotonic versus hypotonic maintenance IV fluids in hospitalized children: A meta-analysis. Pediatrics 2014, 133, 105-113. [CrossRef]

70. Rangaraju, M.; Slator, R.; Richard, B. Post-operative intravenous fluid administration for infant cleft surgery: An observational study. J. Plast. Reconstr. Aesthet. Surg. 2021, 74, 839-844. [CrossRef]

71. Langer, T.; Limuti, R.; Tommasino, C.; Van Regenmortel, N.; Duval, E.L.; Caironi, P.; Malbrain, M.L.; Pesenti, A. Intravenous fluid therapy for hospitalized and critically ill children: Rationale, available drugs and possible side effects. Anaesthesiol. Intensive Ther. 2018, 50, 49-58. [CrossRef]

72. Sahay, M.; Sahay, R. Hyponatremia: A practical approach. Indian J. Endocrinol. Metab. 2014, 18, 760-771. [CrossRef]

73. Rai, A.; Whaley-Connell, A.; McFarlane, S.; Sowers, J.R. Hyponatremia, arginine vasopressin dysregulation, and vasopressin receptor antagonism. Am. J. Nephrol. 2006, 26, 579-589. [CrossRef]

74. Cavari, Y.; Pitfield, A.F.; Kissoon, N. Intravenous maintenance fluids revisited. Pediatr. Emerg. Care 2013, 29, 1225-1231. [CrossRef] [PubMed]

75. Arieff, A.I.; Ayus, J.C.; Fraser, C.L. Hyponatraemia and death or permanent brain damage in healthy children. Br. Med. J. 1992, 304, 1218-1222. [CrossRef]

76. Benzon, H.A.; Bobrowski, A.; Suresh, S.; Wasson, N.R.; Cheon, E.C. Impact of preoperative hyponatraemia on paediatric perioperative mortality. Br. J. Anaesth. 2019, 123, 618-626. [CrossRef]

77. Singhi, S.; Prasad, S.; Chugh, K. Hyponatremia in sick children: A marker of serious illness. Age 1994, 125, 126-130.

78. Kutz, A.; Ebrahimi, F.; Aghlmandi, S.; Wagner, U.; Bromley, M.; Illigens, B.; Siepmann, T.; Schuetz, P.; Mueller, B.; Christ-Crain, M. Risk of adverse clinical outcomes in hyponatremic adult patients hospitalized for acute medical conditions: A population-based cohort study. J. Clin. Endocrinol. Metab. 2020, 105, 3428-3436. [CrossRef] [PubMed]

79. Au, A.K.; Ray, P.E.; McBryde, K.D.; Newman, K.D.; Weinstein, S.L.; Bell, M.J. Incidence of postoperative hyponatremia and complications in critically-ill children treated with hypotonic and normotonic solutions. J. Pediatr. 2008, 152, 33-38. [CrossRef]

80. Chua, H.-R.; Venkatesh, B.; Stachowski, E.; Schneider, A.G.; Perkins, K.; Ladanyi, S.; Kruger, P.; Bellomo, R. Plasma-Lyte 148 vs $0.9 \%$ saline for fluid resuscitation in diabetic ketoacidosis. J. Crit. Care 2012, 27, 138-145. [CrossRef] [PubMed]

81. Mahler, S.A.; Conrad, S.A.; Wang, H.; Arnold, T.C. Resuscitation with balanced electrolyte solution prevents hyperchloremic metabolic acidosis in patients with diabetic ketoacidosis. Am. J. Emerg. Med. 2011, 29, 670-674. [CrossRef]

82. McFarlane, C.; Lee, A. A comparison of Plasmalyte 148 and $0.9 \%$ saline for intra-operative fluid replacement. Anaesthesia 1994, 49, 779-781. [CrossRef]

83. Scheingraber, S.; Rehm, M.; Sehmisch, C.; Finsterer, U. Rapid saline infusion produces hyperchloremic acidosis in patients undergoing gynecologic surgery. Anesthesiology 1999, 90, 1265-1270. [CrossRef] [PubMed]

84. Williams, E.L.; Hildebrand, K.L.; McCormick, S.A.; Bedel, M.J. The effect of intravenous lactated Ringer's solution versus 0.9\% sodium chloride solution on serum osmolality in human volunteers. Anesth. Analg. 1999, 88, 999-1003. [CrossRef] [PubMed]

85. Young, J.B.; Utter, G.H.; Schermer, C.R.; Galante, J.M.; Phan, H.H.; Yang, Y.; Anderson, B.A.; Scherer, L.A. Saline versus Plasma-Lyte A in initial resuscitation of trauma patients: A randomized trial. Ann. Surg. 2014, 259, 255-262. [CrossRef]

86. Bulfon, A.F.; Alomani, H.L.; Anton, N.; Comrie, B.T.; Rochwerg, B.; Stef, S.A.; Thabane, L.; Vanniyasingam, T.; Choong, K. Intravenous fluid prescription practices in critically ill children: A shift in focus from natremia to chloremia? J. Pediatr. Intensive Care 2019, 8, 218-225. [CrossRef]

87. Neville, K.A.; Sandeman, D.J.; Rubinstein, A.; Henry, G.M.; McGlynn, M.; Walker, J.L. Prevention of Hyponatremia during Maintenance Intravenous Fluid Administration: A Prospective Randomized Study of Fluid Type versus Fluid Rate. J. Pediatr. 2010, 156, 313-319. [CrossRef]

88. Sulemanji, M.; Vakili, K. Neonatal renal physiology. Semin. Pediatr. Surg. 2013, 22, 195-198. [CrossRef]

89. Blackburn, S.T. Renal function in the neonate. J. Perinat. Neonatal. Nurs. 1994, 8, 37-47. [CrossRef]

90. Tuzun, F.; Akcura, Y.; Duman, N.; Ozkan, H. Comparison of isotonic and hypotonic intravenous fluids in term newborns: Is it time to quit hypotonic fluids. J. Matern. Fetal Neonatal Med. 2020, 1-6. [CrossRef] 